\title{
MODEL GUIDED INQUIRY DAN GUIDED DISCOVERY DALAM PEMBELAJARAN IPA UNTUK MENINGKATKAN KEMAMPUAN KOGNITIF SISWA SMP
}

\author{
Syafrilianto, Taufik Rahman \\ syafrilianto@gmail.com
}

\begin{abstract}
Penelitian bertujuan untuk mengetahui peningkatan kemampuan kognitif siswa melalui penerapan model guided inquiry dan guided discovery dalam pembelajaran IPA terpadu. Tema sumber energi alternatif dipilih sebagai tema pembelajaran yang memuat konsep IPA Biologi, Fisika, dan Kimia, terdiri atas briket sebagai sumber kalor dan baterai buah sebagai sumber listrik. Penelitian ini menggunakan metode kuasi perlakuan I dengan desain comparison group. Subjek dalam penelitian merupakan siswa kelas VII SMP di Kabupaten Kampar sebanyak 42 siswa yang terdiri dari dua kelas homogen yaitu kelas perlakuan I (Guided Inquiry) dan kelas perlakuan II (Guided Discovery) dengan jumlah 21 siswa pada masing-masing kelas. Adapun karakteristik kedua kelas yaitu memiliki rata-rata tingkat IQ yang sama berdasarkan data nilai ulangan harian sebelumnya. Penentuan subjek dipilih dengan teknik non-randomized sampling karena tidak dimungkinkan untuk mengubah susunan anggota kelas yang telah ditetapkan oleh sekolah. Hasil belajar kognitif siswa diukur menggunakan instrumen tes soal pilihan ganda, terdiri atas 21 butir soal tes kemampuan kognitif yang dilakukan sebanyak dua kali (pretest dan posttest menggunakan instrumen tes yang sama). Teknik analisis data yang digunakan dalam penelitian yaitu uji normalitas dan uji hipotesis (uji U). Analisis data menggunakan program IBM SPSS 22 statistics dan Microsoft Excell 2010. Nilai rata-rata N-Gain kemampuan kognitif menunjukkan adanya peningkatan kemampuan kognitif siswa kelas perlakuan I sebesar 0,44 dengan kategori sedang dan kelas perlakuan II sebesar 0.21 dengan kategori rendah. Sedangkan hasil uji $U$ terhadap nilai $N$ Gainnya menunjukkan bahwa terdapat perbedaan yang signifikan pada kemampuan kognitif antara siswa kelas perlakuan I dan kelas perlakuan II. Dengan demikian dapat disimpulkan bahwa model guided inquiry lebih dapat meningkatkan kemampuan kognitif siswa SMP dibandingkan dengan model guided discovery.
\end{abstract}

Kata kunci: model guided inquiry, model guided discovery, kemampuan kognitif, sumber energi alternatif

\section{PENDAHULUAN}

Ilmu Pengetahuan Alam (IPA) pada hakikatnya merupakan suatu produk dan proses ilmiah serta aplikasi. IPA sebagai produk dapat dipandang sebagai sekumpulan pengetahuan, konsep dan bagan konsep. IPA sebagai proses merupakan langkah-langkah ilmiah yang dipergunakan untuk mempelajari objek studi, menemukan dan mengembangkan 
produk-produk sains yang lazim disebut metode ilmiah (scientific method). Sedangkan sebagai aplikasi, teori-teori IPA akan melahirkan teknologi yang dapat memberikan kemudahan bagi kehidupan (Trianto, 2014). Dengan demikian, IPA bukan hanya penguasaan sekumpulan pengetahuan yang berupa faktafakta, konsep maupun prinsip saja, tetapi juga merupakan suatu proses penemuan terhadap pengetahuan itu sendiri melalui langkah-langkah atau metode ilmiah

Berdasarkan hakikat IPA tersebut, maka pembelajaran IPA di sekolah diharapkan dapat menjadi wahana bagi peserta didik untuk mempelajari diri sendiri dan alam sekitarnya serta mampu menerapkan pengetahuan tersebut dalam kehidupan sehari-hari. Pembelajaran IPA juga menekankan pada pengalaman langsung untuk mengembangkan kemampuan peserta didik sehingga memiliki kompetensi dalam memahami alam sekitar melalui proses mencari tahu dan melakukan, sehingga dapat membantu mereka untuk memperoleh keterampilan dan pemahaman yang lebih mendalam terhadap IPA. Oleh karena itu, melalui kegiatan dan pengalaman belajar IPA diharapkan siswa memiliki berbagai macam keterampilan termasuk keterampilan kognitif (intelektual), manual (psikomotor) dan sosial (sikap). Keterampilan-keterampilan tersebut merupakan keterampilanketerampilan yang terlibat dalam kemampuan kognitif (Rustaman, 2005).
Praktek yang terjadi di sekolah, sebagian besar kegiatan pembelajaran IPA yang dilakukan belum mampu mewujudkan suasana belajar dan proses pembelajaran yang menjadikan siswa aktif dan terlibat secara langsung, artinya pembelajaran tersebut belum dapat memfasilitasi siswa dalam mengembangkan berbagai potensi, kemampuan maupun keterampilan mereka secara optimal termasuk kemampuan kognitifdan kemampuan kognitifnya. Hal ini dibuktikan dengan studi pendahuluan yang dilakukan peneliti melalui wawancara dengan guru IPA serta melakukan analisis terhadap kemampuan siswa kelas VII di salah satu SMP negeri di Kabupaten Kampar.

Studi pendahuluan yang telah dilakukan tersebut memberikan gambaran bahwa kemampuan kognitif siswa kelas VII berdasarkan tes ulangan harian yang diberikan kepada siswa selama ini belum memuaskan. Kebanyakan soal-soal yang diujikan hanya sampai pada tingkat pengetahuan $\left(\mathrm{C}_{1}\right)$ dan pemahaman $\left(\mathrm{C}_{2}\right)$, padahal tingkatan kemampuan koginitif menurut taksonomi Bloom yang direvisi terdiri atas enam tingkatan mulai dari level $\mathrm{C}_{1} \quad$ (mengingat), $\quad \mathrm{C}_{2}$ (memahami), $\mathrm{C}_{3}$ (mengaplikasi), $\mathrm{C}_{4}$ (menganalisis), $\mathrm{C}_{5}$ (mengevaluasi) hingga level $\mathrm{C}_{6}$ (mencipta) (Anderson \& Krathwol, 2010). Dengan demikian dapat dipahami bahwa pengalaman belajar yang diperoleh siswa dalam mengembangkan kemampuan kognitif mereka belum optimal bahkan jarang mereka dapatkan 
ketika melakukan kegiatan pembelajaran IPA di sekolah.

Solusi untuk mengatasi persoalan dan kendala dalam pembelajaran IPA yang telah dikemukakan adalah melalui penerapan model guided inquiry dan guided discovery dalam pembelajaran IPA terpadu di sekolah. Pembelajaran berbasis inkuiri sesuai dengan pencarian pengetahuan secara aktif oleh siswa dan dengan sendirinya memberikan hasil yang paling baik karena mereka didorong untuk mencari pemecahan masalah sendiri sehingga menghasilkan pengetahuan yang benar-benar bermakna (Dahar, 2011).

Meskipun model guided inquiry dan guided discovery merupakan pembelajaran berbasis inkuiri, namun antara kedua model tersebut memiliki perbedaan dari segi porsi keterlibatan siswa ketika diterapkan dalam pembelajaran dimana model guided inquiry lebih banyak melibatkan siswa secara aktif dan langsung dalam pembelajaran dibandingkan dengan model guided discovery. Hal ini dapat dilihat dari sintaks pembelajaran pada masingmasing model yaitu model guided inquiry terdiri atas tahap orientasi dan pengajuan masalah, merumuskan masalah, mengajukan hipotesis, mengumpulkan data, melakukan percobaan untuk menguji hipotesis, dan merumuskan kesimpulan (Hosnan, 2014). Sedangkan sintaks model guided discovery terdiri atas tahap motivation, data collection, data processing, dan closure (Howe \& Jones, 1993).

Dengan demikian, melalui penerapan kedua model tersebut, maka siswa akan memperoleh pengalaman belajar yang berbeda dalam melatihkan dan mengembangkan kemampuan kognitif mereka.

Berdasarkan uraian latar belakang masalah yang telah dikemukan, maka rumusan masalah dalam penelitian ini adalah "Bagaimanakah perbedaan peningkatan kemampuan kognitif siswa melalui penerapan model guided inquiry dibandingkan dengan model guided discovery dalam pembelajaran IPA pada tema sumber energi alternatif?".

Tujuan penelitian adalah dapat mengetahui perbedaan peningkatan kemampuan kognitif siswa dengan menerapkan model guided inquiry dan guided discovery dalam pembelajaran IPA di SMP. Adapun hipotesis penelitiannya yaitu model guided inquiry lebih dapat meningkatkan kemampuan kognitif siswa SMP dibandingkan dengan model guided discovery.

\section{METODE PENELITIAN}

Penelitian ini menggunakan metode kuasi perlakuan I dengan desain comparison group. Populasi penelitian terdiri dari 90 siswa kelas VII di salah satu SMP negeri di Kabupaten Kampar dengan sampel penelitian sebanyak 42 siswa, terdiri dari kelas perlakuan I (guided inquiry) dan kelas perlakuan II (guided discovery) dengan jumlah 21 siswa pada masing-masing kelas. yang dipilih dengan teknik nonrandomized sampling. Hal ini disebabkan karena tidak dimungkinkan untuk mengubah susunan anggota kelas yang telah ditetapkan oleh sekolah, artinya 
peneliti memilih sampel penelitian berdasarkan susunan kelas yang tersedia serta lebih mudah atau cocok (conveniently) dengan tujuan dan karakteristik penelitian yang akan dilaksanakan. Alasan pemilihan sampel tersebut sejalan dengan pendapat Creswell (2013) yang menyatakan bahwa dalam beberapa penelitian eksperimen, hanya sampel convenience-lah yang memiliki kemungkinan untuk terpilih sebab peneliti biasanya menggunakan kelompok-kelompok yang sudah terbentuk secara alamiah (seperti sebuah kelas, organisasi, atau sebuah keluarga).

Tema pembelajaran yang digunakan sama yaitu sumber energi alternatif (briket dan baterai buah), memuat konsep IPA Biologi, Fisika, dan Kimia. Pembelajaran di sekolah dilaksanakan sebanyak lima pertemuan.

Kemampuan kognitif siswa diukur dengan tes soal pilihan ganda sebanyak 21 butir soal dengan tema sumber energi alternatif (briket dan baterai buah) yang memuat konsep

kalor, perubahan fisika dan kimia, asam basa, energi listrik, sel volta serta rangkaian seri paralel. Tes kemampuan kognitif ini dilaksanakan di awal pertemuan sebelum diberikan perlakuan yang berbeda terhadap siswa kelas perlakuan I dan kelas perlakuan II serta di akhir pertemuan setelah perlakuan. Adapun kemampuan kognitif siswa yang diukur dalam tes ini mengacu kepada taksonomi Bloom revisi yang dikemukakan oleh Anderson dan Krathwohl (2010).

Data penelitian diperoleh melalui pemberian tes soal kemampuan kognitif sebanyak 21 butir soal pada masing-masing kelas. Adapun uji prasyarat dan uji hipotesis yang digunakan dalam penelitian ini adalah uji normalitas dan uji $\mathrm{U}$.

\section{HASIL DAN PEMBAHASAN}

Rekapitulasi hasil data pretest, posttest, dan gain yang dinormalisasi ( $N$-Gain) kemampuan kognitif siswa pada masing-masing kelas disajikan dalam tabel 1.

TABEL 1. REKAPITULASI NILAI RATA-RATA PRETEST, POSTTEST DAN N-GAIN KEMAMPUAN KOGNITIF SISWA SMP

\begin{tabular}{lcccccccc}
\hline Keterampilan & \multicolumn{3}{c}{ Kelas Perlakuan I } & \multicolumn{5}{c}{ Kelas Perlakuan II } \\
\cline { 2 - 9 } Proses Sains & Pretest & Posttest & N-Gain & Kategori & Pretest & Posttest & N-Gain & Kategori \\
Nilai Min & 19,05 & 28,57 & & & 14,29 & 23,81 & & \\
Nilai Maks & 61,90 & 95,24 & & & 66,67 & 80,95 & & \\
Nilai Rata-rata & 35,15 & 62,59 & 0,44 & Sedang & 34,01 & 47,39 & 0,21 & Rendah \\
& & & & & & & & \\
\% Rata-Rata & 35,15 & 62,59 & 44 & & 34,01 & 47,39 & 21 &
\end{tabular}

Berdasarkan tabel 1 terlihat bahwa terdapat perbedaan peningkatan kemampuan kognitif siswa antara kelas perlakuan I dan kelas perlakuan II baik secara kuantitatif maupun kualitatif. Kelas perlakuan I mengalami peningkatan kemampuan kognitif sebesar 0,44 dengan kategori sedang, sedangkan kelas perlakuan II mengalami peningkatan sebesar 0,21 dengan kategori rendah. Untuk melihat perbandingan nilai rata-rata pretest, posttest dan N-Gain kemampuan kognitif siswa pada kelas perlakuan I dan kelas perlakuan 
II, berikut ini disajikan dalam bentuk grafik seperti Gambar 1.

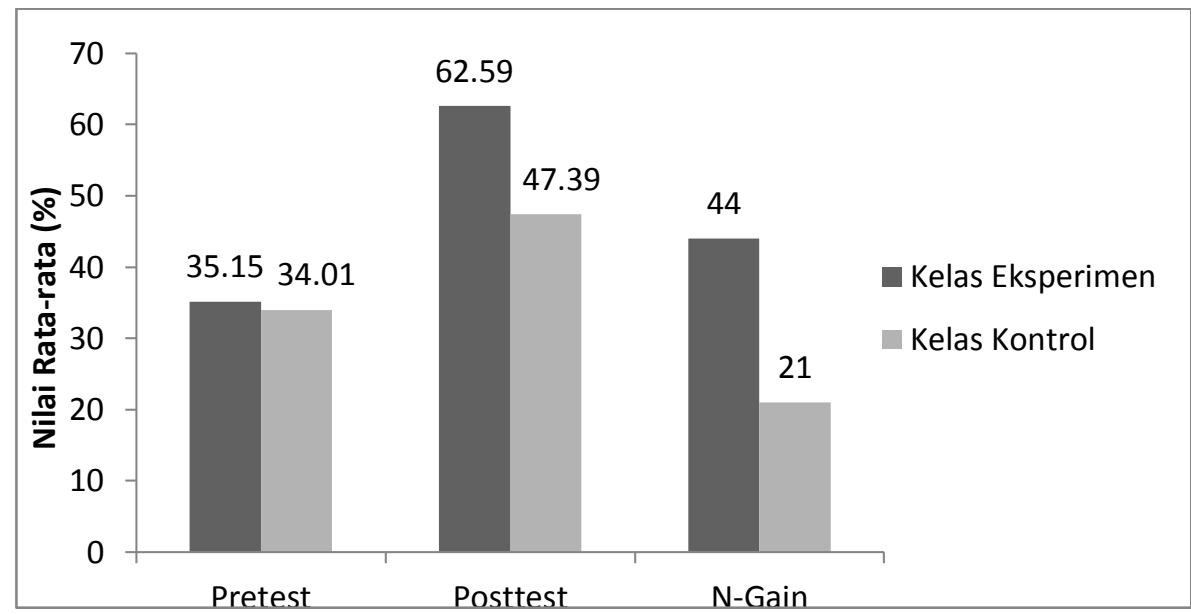

Gambar 1. Grafik Perbandingan Nilai Rata-Rata Pretest, Posttest dan N-Gain Kemampuan Kognitif Kelas Perlakuan I dan Kelas Perlakuan II

Gambar 1 mendeskripsikan bahwa nilai rata-rata pretest kelas perlakuan I dan kelas perlakuan II hampir sama, yaitu 35,15 untuk kelas perlakuan I dan 34,01 untuk kelas perlakuan II dari nilai ideal 100. Namun untuk nilai rata-rata posttest, kelas perlakuan I memiliki nilai lebih tinggi dibandingkan dengan kelas perlakuan II dengan nilai masingmasing yaitu 62,59 dan 47,39. Adapun peningkatan nilai rata-rata pretest dan posttest pada masingmasing kelas diwakili oleh perolehan rata-rata gain yang dinormalisasi $(\mathrm{N}$ Gain) dengan perbandingan antara kelas perlakuan I dan kelas perlakuan II dalam persen yaitu sebesar 44 dan 21. Dengan demikian, kelompok siswa pada kelas perlakuan I mengalami peningkatan kemampuan kognitif yang lebih tinggi dibandingkan dengan kelompok siswa pada kelas perlakuan II secara keseluruhan.

Sedangkan deskripsi peningkatan kemampuan kognitif siswa pada tiap jenjang atau level kognitif yang diwakili oleh nilai $\mathrm{N}$ Gain masing-masing level untuk kelas perlakuan I dan kelas perlakuan II ditunjukkan pada Gambar 2

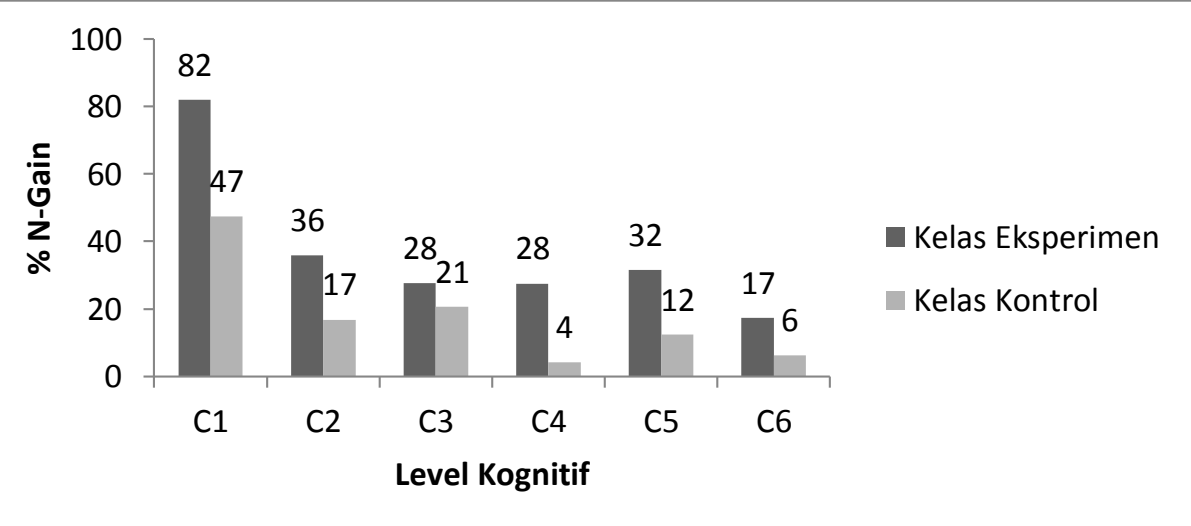

Gambar 2. Grafik Rata-Rata Nilai N-Gain Tiap Level Kognitif pada Kelas Perlakuan I dan Kelas Perlakuan II 
Berdasarkan Gambar 2, peningkatan kemampuan kognitif siswa tertinggi di kelas perlakuan I terdapat pada level $\mathrm{C}_{1}$ (mengingat) yaitu sebesar 82\%, sedangkan peningkatan kemampuan kognitif siswa terendah terdapat pada level $\mathrm{C}_{6}$ (mencipta) yaitu sebesar $17 \%$. Adapun pada kelas perlakuan II, peningkatan kemampuan kognitif siswa paling tinggi terdapat pada level $\mathrm{C}_{1}$ (mengingat) yaitu sebesar $47 \%$, sedangkan peningkatan kemampuan kognitif siswa terendah terdapat pada level $\mathrm{C}_{4}$ (menganalisis) yaitu sebesar $4 \%$.

Selanjutnya, hasil analisis statistik nilai $\mathrm{N}$-Gain kemampuan kognitifsiswa kelas perlakuan I disajikan dalam Tabel 2.

TABEL 2. ANALISIS STATISTIK $N$-GAIN KEMAMPUAN KOGNITIF KELAS PERLAKUAN I DAN KELAS PERLAKUAN II

\begin{tabular}{|c|c|c|c|c|}
\hline Uji Statistik & $\mathrm{N}$ & $\alpha$ & Sig. & Kesimpulan \\
\hline \multicolumn{5}{|l|}{ Uji Normalitas } \\
\hline Perlakuan I & 21 & 0.05 & 0.200 & Data normal \\
\hline Perlakuan II & 21 & 0.05 & 0.012 & Data tak normal \\
\hline Uji $U$ & 42 & 0.05 & 0.000 & $\begin{array}{l}\text { Terdapat } \\
\text { signifikan }\end{array}$ \\
\hline
\end{tabular}

Berdasarkan Tabel 2 terlihat bahwa nilai N-Gain pada kelas perlakuan I berdistribusi normal, sedangkan pada kelas perlakuan II berdistribusi tidak normal. Oleh karena itu, dilanjutkan dengan uji $U$ untuk menguji hipotesisnya. Uji U menunjukkan bahwa terdapat perbedaan peningkatan kemampuan kognitif siswa antara kelas perlakuan I dan kelas perlakuan II, dimana siswa kelas perlakuan I mengalami peningkatan yang lebih besar dibandingkan dengan siswa kelas perlakuan II.

Terjadinya perbedaan peningkatan kemampuan kognitif siswa antara kelas perlakuan I dan kelas perlakuan II tidak terlepas dari perlakuan berbeda yang diterima oleh kelompok siswa pada kedua kelas tersebut. Meskipun pembelajaran yang diterapkan samasama berbasis penemuan, namun kelas perlakuan I yang melaksanakan kegiatan pembelajaran model guided inquiry memiliki porsi keterlibatan siswa secara langsung lebih besar dibandingkan dengan kelompok siswa kelas perlakuan II yang melaksanakan pembelajaran dengan model guided discovery. Hal ini disebabkan karena tingkatan pembelajaran inquiry itu sendiri lebih tinggi dibandingkan dengan pembelajaran discovery. Di samping itu, pembelajaran discovery merupakan bentuk atau tingkatan paling dasar dari pembelajaran yang berorientasi pada inkuiri (Wenning, 2005).

Model guided inquiry dan guided discovery merupakan model pembelajaran yang berbasis inkuiri, namun model guided inquiry lebih dapat meningkatkan kemampuan kognitif siswa karena sesuai dengan pencarian pengetahuan secara aktif oleh peserta didik dan dengan sendirinya akan memberikan hasil yang paling baik (Bruner dalam Dahar, 2011). Keterlibatan dan keaktifan siswa dalam mengikuti pembelajaran dapat dilihat dari setiap tahapan pembelajaran guided inquiry yang dilaksanakan mulai tahap orientasi dan pengajuan masalah, merumuskan masalah, merumuskan 
hipotesis, mengumpulkan data, menguji hipotesis melalui perlakuan I serta merumuskan kesimpulan. Misalnya pada tahap orientasi dan pengajuan masalah, siswa diminta untuk mengamati secara langsung fenomena atau masalah yang disajikan oleh guru melalui demonstrasi, setelah itu siswa diminta untuk mengajukan pertanyaan terkait dengan pengamatan tersebut. Hal ini menunjukkan bahwa siswa dituntut untuk terlibat secara aktif dan langsung dalam mengikuti pembelajaran pada tahap tersebut baik secara personal maupun dalam kelompoknya.

Selanjutnya, pada tahap merumuskan masalah dan merumuskan hipotesis siswa juga diminta untuk aktif menggali informasi terkait dengan rumusan masalah yang telah mereka ajukan melalui berbagai sumber belajar termasuk juga dari bahan bacaan yang telah dibagikan oleh guru untuk kemudian memperoleh jawaban sementara dari rumusan masalah tersebut yang dikenal sebagai hipotesis. Demikian juga ketika siswa melaksanakan kegiatan pembelajaran pada tahap mengumpulkan data, menguji hipotesis melalui perlakuan I hingga merumuskan kesimpulan yang pada akhirnya mereka menemukan konsep dengan sendirinya terkait dengan tema pembelajaran yang dipelajari tersebut. Dengan demikian, melalui tahapa-tahapan dalam model guided inquiry tersebut siswa akan memperoleh kebermaknaan dalam pembelajaran. Belajar yang bermakna menghadirkan pengetahuan dan proses-proses kognitif yang siswa butuhkan dalam menyelesaikan masalah (Anderson dan Krathwohl, 2010).

\section{PENUTUP}

Berdasarkan analisis dan uraian hasil penelitian dan pembahasan di atas, maka dapat disimpulkan bahwa penerapan model guided inquiry dalam pembelajaran IPA lebih dapat meningkatkan kemampuan kognitif siswa dibandingkan dengan model guided discovery. Peningkatan tertinggi terdapat pada level kognitif $\mathrm{C}_{1}$ (mengingat) baik pada kelas perlakuan I maupun kelas perlakuan II. Sedangkan peningkatan terendah terdapat pada level kognitif $\mathrm{C}_{6}$ (mencipta) untuk kelas perlakuan I dan level $\mathrm{C}_{4}$ (menganalisis) untuk kelas perlakuan II.

\section{DAFTAR PUSTAKA}

Anderson dan Krathwol. 2010. Kerangka Landasan untuk Pembelajaran, Pengajaran, dan Asesmen. Jogjakarta: Pustaka Pelajar.

Creswell, J.W. 2013. Research Design (Pendekatan Kualitatif, Kuantitatif, dan Mixed). Jogjakarta: Pustaka Pelajar.

Dahar. 2011. Teori-teori Belajar dan Pembelajaran. Jakarta: Erlangga.

Hosnan, M. 2014. Pendekatan Saintifik dan Kontekstual dalam Pembelajaran Abad 21. Bogor: Ghalia Indonesia.

Howe, A.C dan Jones, L. 1993. Engaging Children in Science. New York: 
Macmillan Publishing

Company.

Rustaman, N. 2005. Strategi Belajar Mengajar Biologi. malang: Universitas Negeri Malang.

Trianto. 2014. Model pembelajaran Terpadu: Konsep, Strategi, dan Implementasinya dalam
KTSP. Jakarta: PT. Bumi Akasara.

Wenning, C. J. 2005. Levels of inquiry: Hierarchies of pedagogical practices and inquiry processes. Journal Physics Teacher Education Online, 2(3), 3-12. 